\title{
EGY KISTELEPÜLÉSI KÖNYVTÁR(OS) ESZKÖZEI ÉS LEHETŐSÉGEI A KÖZÖSSÉGFEJLESZTÉS TERÜLETÉN
}

\section{PARAGINÉ TÓTH EDINA}

\section{Tartalmi összefoglaló}

A Zákányszéki Müvelödési Ház és Könyvtár tetöterében kapott helyet 2010-ben a kistelepülés könyvtára. Az új teret új bútorokkal úgy alakították ki, hogy egyaránt alkalmas legyen csendes olvasásra és élénk közösségi színtérként. A terek berendezése során épitettek az olvasók kreativitására is. A közösségfejlesztés területén az egyszemélyes könyvtár és könyvtárosa a hagyományos rendezvények mellett a civil szféra bevonására törekszik, jó kapcsolatokat ápol a helyi intézményekkel és felvállalta a helyi újság kiadói teendöit.

https://doi.org/10.46280/KOMPKONF.2020.Paragine

„Ha sok cseresznyepaprikát madzagra füzünk, abból lesz a paprikakoszorú.

Ha viszont nem füzzük fel őket, nem lesz belölük koszorú. Pedig a paprika ugyanannyi, éppoly piros, éppoly erős. De mégse koszorú. Csak a madzag tenné? Nem a madzag teszi. Az a madzag, mint tudjuk, mellékes, harmadrangú valami. Hát akkor mi? Aki ezen elgondolkozik, s ügyel rá, hogy gondolatai ne kalandozzanak összevissza, hanem helyes irányban haladjanak, nagy igazságoknak jöhet a nyomára."

(Örkény István: Az élet értelme)

\section{Bemutatkozás}

Zákányszék tipikus homoki tanyásfalu. Szegedtől húsz km távolságra található Csongrád megyében, a lakosságszám már évtizedek óta nem éri el a háromezer főt. Jellemzője a nagy kiterjedésű tanyavilág, a mezőgazdasági termelés, küzdelem a szélsőséges időjárással és a homokkal. Szerencsére azonban nem csak erről szól a 2800 fős település élete. További jellemzője még a tradicionális paraszti értékrend tisztelete, a hagyományok ápolása, a pezsgő kulturális élet.

Születésem óta Zákányszéken élek. Ide kötnek több generációra visszamenőleg a gyökereim, ide köt a családom és ide köt a munkahelyem, ahol nemcsak munkalehetőséget, hanem a hivatásomat is megtaláltam. Mindez elég indok arra, hogy fö motivációm, a 
falusi értékrend megőrzése, átörökítése, a hagyományok tisztelete és ápolása, a helyi közösség fejlesztése legyen munkám valamennyi területén.1986 óta vagyok a Zákányszéki Művelődési Ház és Könyvtár dolgozója, kezdetben az intézmény megbízott vezetője, majd 1988-tól az egyszemélyes könyvtár könyvtárosa. ${ }^{1}$ Munka mellett középfokú képesítéseket szereztem népmüvelö, könyvtárkezelö, könyvtáros asszisztens tanfolyami képzéseken, majd a főiskolán könyvtár, illetve pedagógia szakon folytattam tanulmányaimat. Harmadik ciklusban választottak meg a kollégák a Csongrád Megyei Könyvtárosok Egyesülete elnökségi tagjának, Szeged és a Homokhátság könyvtárait képviselem a kilenc főből álló vezetőségben. 2014-ben Tündérkönyvtáros oklevelet vehettem át Budapesten az olvasók szavazatainak köszönhetően. Erre vagyok talán a legbüszkébb! ${ }^{2}$

Nagy megtiszteltetés számomra, hogy könyvtárosi pályafutásom alatt több alkalommal előadója lehettem térségi találkozóknak és országos konferenciáknak. ${ }^{3}$ Lehetőségem nyílt bemutatni a településemet és a „könyvtáramat”, valamint az egyesületi tevékenységünket és a közösségfejlesztés területén elért tapasztalatokat. 2008-ban a ZakaHom-e Egyesület egyik alapító tagja voltam, azóta az egyesületi munkával egészül ki a könyvtárosi tevékenységem. Sok egyesületi program helyszíne a könyvtár, és a könyvtár munkája is beleolvad a civil törekvésekbe. Hangsúlyos terület számomra a helyi újságok szerkesztőbizottsági munkája és egyéb „médiás” feladatok (riportok, képes beszámolók, kisfilmek készítése, fotózás), a múltidéző vetítések elindítása, ifjú tehetségek és alkotók segítése, jótékonysági kezdeményezések, kerékpártúrák szervezése. A civil csapatmunka jól kompenzálja az egyszemélyes könyvtárosság határait.

Fő törekvésem, hogy a lakosság és a könyvtár használói ne hátrányként éljék meg a kistelepülési létet az információhoz jutás, az olvasás, a müvelődés, a kulturált szórakozás terén. Ha jelképesen sikerül „hidat képezni” az igény és a lelőhely között, ha elérhető távolságba kerülnek az egyébként távolinak tünő lehetőségek... akkor kevésbé lesznek élesek a határok kis- és nagytelepülések között.

\section{Egy könyvtár, három tér...}

A Zákányszéki Müvelödési Ház és Könyvtár hivatalos nevet viselő intézményben a község könyvtára közel tízezer kötetes állománnyal rendelkezik. A beiratkozott olvasók száma átlagosnak mondható: 300-400 fő között mozog, 11-14\%-a település teljes lakosságának. 2018 januárjában elindult a könyvtárban a számítógépes kölcsönzés, előző évben mindezt

1 ZakaHom-e Egyesület: Paraginé Tóth Edina több, mint 30 éve a köz szolgálatában.

Forrás: http://www.zakahome.hu/2016/02/09/paragine-toth-edina-tobb-mint-30-eve-a-koz-szolgalataban/ [2018. november 12.]

2 Tündérkönyvtáros Zákányszéken. = Délmagyarország, 2014. július 2. 6. p.

Forrás: http://www.delmagyar.hu/szeged_hirek/tunderkonyvtaros_zakanyszeken/2388422/[2018. november 10.]

3 MIKULÁS Gábor: A könyvtári ellátás korszerű formái az EU-ban: Antwerpen, Zákányszék, Madrid...

Forrás: http://www.kithirlevel.hu/index.php?kh=a_konyvtari_ellatas_korszeru_formai_az_eu-ban_antwerpen_zakanyszek_ madrid [2018. november 10.] 
megelőzte a teljes állomány vonalkóddal történő ellátása és rögzítése a Corvina adatbázisban. A könyvtár önálló honlapja a konyvtar.zakanyszek.hu weboldalon érhető el.

Bár életem első munkahelyén dolgozom, mégis elmondhatom, hogy három különböző térben voltam már könyvtáros. Ennek „ára” két költözés volt, először 2002-ben, majd 2010ben. Amikor a költözés ténye abból fakad, hogy más funkciót szánnak a könyvtárhelyiségnek, nem törvényszerüen értékeli a könyvtáros pozitívumként a változást. Nagymértékben meghatározza a könyvtár szerepét, megítélését, hogy a települési térképen hol található. Központi helyen van-e, az akadálymentesítés megoldott-e, mekkora az alapterülete, zsúfolt vagy könnyen áttekinthető, milyen infrastruktúrával, tárgyi feltételekkel rendelkezik? Bár esetünkben mindkét költözés kényszerhelyzetből fakadt, idővel mégis pozitív változásokat hozott. Az új hely új lehetőségeket tartogatott. A 2010. évi változásokat szeretném most elsősorban részletezni: ekkor került a könyvtár jelenlegi helyére, a müvelődési ház $120 \mathrm{~m}^{2}$-es tetőterébe.

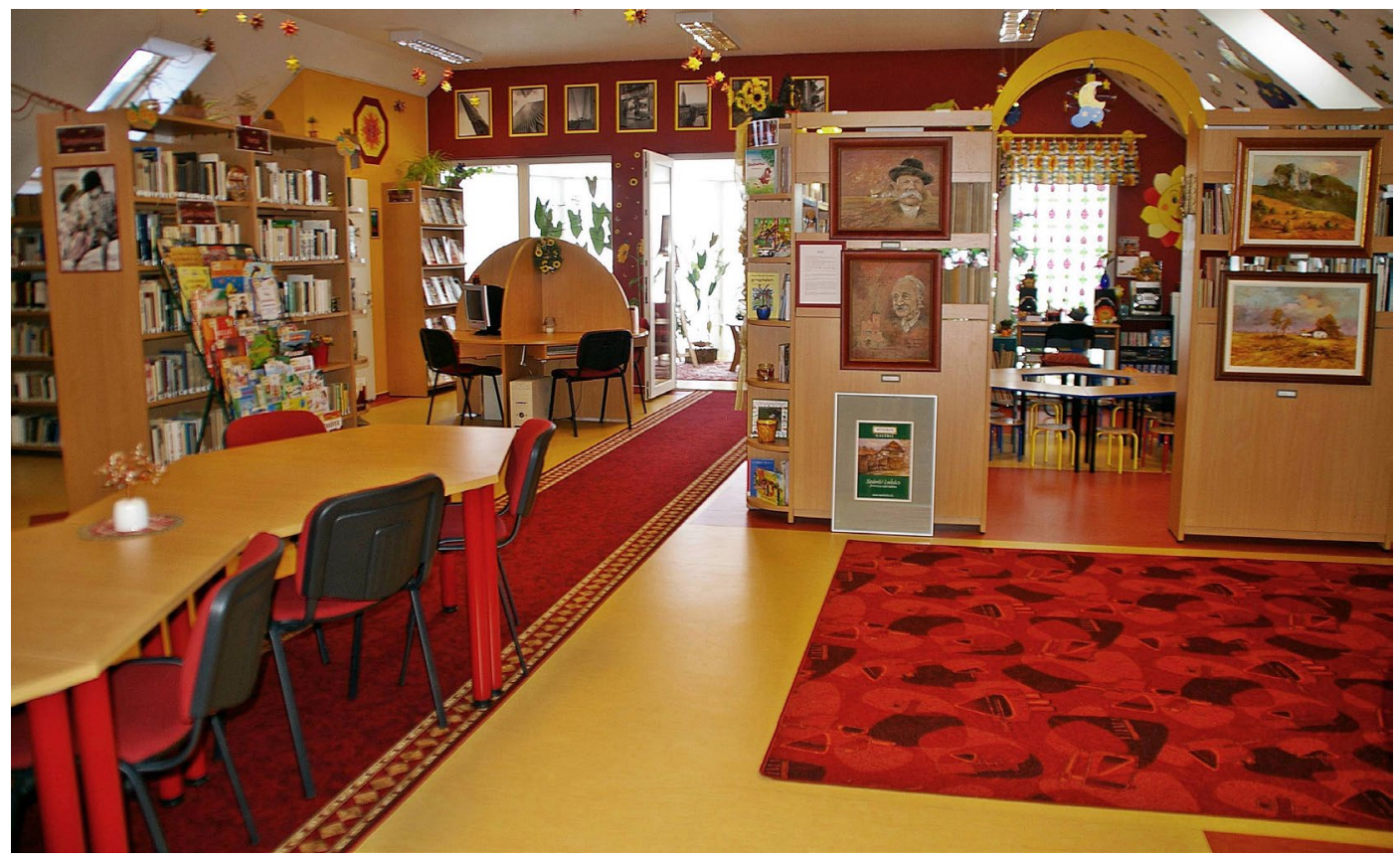

1. kép: A $120 m^{2}$-es könyvtárhelyiség a müvelödési ház tetöterében

Eleinte aggályos volt, hogy a tetőtéri könyvtárban a tudatos könyvtárlátogatókon kívül lesznek-e majd „véletlenül” betérők, akik az előző, központi helyen gyakran váltak „alkalom szülte” olvasókká. A tetőtéri könyvtár első pozitívuma az akadálymentesítés volt, a település egyetlen liftje azóta is a tudomány és a szépirodalom birodalmába emel. ${ }^{4}$ Tréfásan azt szoktam mondani, ha valaki Zákányszéken liftbe száll, garantáltan a könyvtárban találja magát...

4 Vámpírokért és Babócáért jön az olvasó. = Délmagyarország, 2010. november 24. 6. p.

Forrás: http://www.delmagyar.hu/szeged_hirek/vampirokert_es_babocaert_jon_az_olvaso/2190401[2018. november 12.] 
A könyvtár költöztetése és az új tér kialakítása, a térrendezés folyamata összetett és jövőbe mutató feladat, éppen ezért nagy felelősség. A könyvtáros leginkább egyéni ötleteire, saját tapasztalataira hagyatkozhat. Esetemben a cél adott volt: a könyvtári tér legyen alkalmas a szórakozásra, tanulásra, kutatómunkára, a csendes kikapcsolódásra, és legalább ennyire alkalmas legyen a különböző létszámú, összetételü, érdeklődési körű közönségnek szóló rendezvények megvalósítására.

\section{1 Új tér, új lehetóségek}

Az új tér új lehetőségeket - és egyben kihívásokat - jelentett. Sok töprengés, ötletelés előzte meg a költözést. Csak remélni mertem, hogy a tetőtérben nem egy külvilágtól elzárt helyre kerül a könyvtár, hanem folytatni lehet a már jól müködő elgondolásokat. Az új lehetőségek ellenére kicsit mindent elölröl kellett kezdeni...

Az NKA-tól nyert 2 millió forintos pályázati támogatásnak köszönhetően új bútorok készültek a speciális térbe, a polcok egyedi elhelyezésével különbözö öblök alakultak ki (gyerekkuckó, szépirodalmi öböl, olvasóterem, télikert). A gyerekkuckót elválasztó, térben elhelyezett polcrendszer szem előtt lévő hátoldala parafaborítást kapott, ami ideális kiállítási felületként funkcionál. Az olvasóterembe és a gyerekkuckóba jól variálható, trapéz alakú asztalok kerültek, melyek mobilitásuk miatt vetélkedők, csapatmunkák során jó szolgálatot tesznek.

Amikor minden bútorzat és dokumentum a helyére került, kissé fáradtan, de elégedetten hátradőltem: Kész! - gondoltam. Azonban a fejemben motoszkált egy idézet: „Minden könyvtárnak két lényeges alkotórésze van, egy anyagi: a könyvek... s egy szellemi: a könyvtárnok." (Toldy Ferenc) Felmerült bennem a kérdés, hogy vajon én, mint a könyvtár szellemi alkotórésze, mit tudok majd az új könyvtár tárgyi, anyagi alkotórészéhez hozzátenni?

Egy valamiben azonban biztos voltam: a jövőben is mindent el fogok követni annak érdekében, hogy a könyvtárhasználók ne szenvedjenek hátrányt a kultúra, a dokumentumokhoz való hozzáférés, az információszolgáltatás terén azért, mert egy kistelepülés lakói. Öket is ugyanazok a jogok illetik meg, mint bárhol máshol az országban vagy a világban élő embereket. Igyekeztem mindig e szempontok szerint szolgáltatni, mégis nagyon pozitív élmény volt a gyakorlatban is megtapasztalni azt, amit addig csak elméletben tudtam.

2010-ben egy egyetemista lány olyan könyvet keresett a zákányszéki könyvtárban, amely Magyarország egyetlen könyvtárában sem volt megtalálható. Ekkor az Országos Széchényi Könyvtár munkatársaihoz fordultam segítségért. Arra kértem őket, hogy segítsenek a kérést eljuttatni a megfelelő helyre. Azonnal intézkedtek, és a keresett könyvritkaság a kéréstől számított 14. napon megérkezett Zákányszékre, benne az Alaszkai Állami Könyvtár (Alaska State Library) bélyegzőjével! Ekkor értettem meg igazán, hogy nincsenek határok, nincs lehetetlen... egy kistelepülésen sem vagyunk elzárva a világ dokumentumtermésétől! ${ }^{5}$ De szeretnék még egy kicsit visszakanyarodni a könyvtári környezet és berendezés fontosságához.

5 BAKOS András: Alaszkából 14 nap alatt Zákányszékre ér a kért könyv. = Délmagyarország, 2013. február 4. 8. p. Forrás: http:// www.delmagyar.hu/szeged_hirek/alaszkabol_14_nap_alatt_zakanyszekre_er_a_kert_konyv/2318318/ [2018. november 9.] 
Egyre inkább hangsúlyossá válik az a jogos elvárás, hogy a könyvtár egyszerre legyen a nyugalom szigete, valamint egy olyan közösségi színtér, amely alkalmas a különböző igényü és összetételü közönség és közösség bevonzására. Meggyőződésem, hogy a könyvtár külső megjelenésével is kommunikál a külvilág felé. Azt az üzenetet hordozza, hogy fontos, aki az ajtón belép. Azonnal megérzik, hogy ez egy olyan hely, ahol minden értük és nekik szól. A látogatók különösen nagyra értékelik mai rohanó világunkban a könyvtár nyugalmat árasztó, vidám, esztétikus miliőjét.

\subsection{Mire jó a kreativitás?}

A könyvtárról a környezet, a színvilág, a berendezés, a dekorációk összhatása adja az első benyomást a látogatók számára. Mint sok más könyvtárban, nálunk is a dekorációk, a szezonális díszek elsősorban az újrahasznosítás jegyében készültek és készülnek folyamatosan (régi könyvek, teafilter tasakok, naptárlapok, színes kartonok, üres üvegek felhasználásával). Ez több szempontból is előnyös: egyrészt a könyvtáros fejlesztheti kreatív énjét az alkotás folyamatában, másrészt költséghatékony módon esztétikus látványt tudunk nyújtani filléres alapanyagokból. Ezen kívül van még egy pozitív hozadék, ugyanis a kreativitás is építhet közösséget. Hogyan? A könyvtár ideális helyszíne a kreatív emberek találkozásának, alkotásaik bemutatásának, ismereteik továbbadásának. Ebben a könyvtáros célzottan is tud

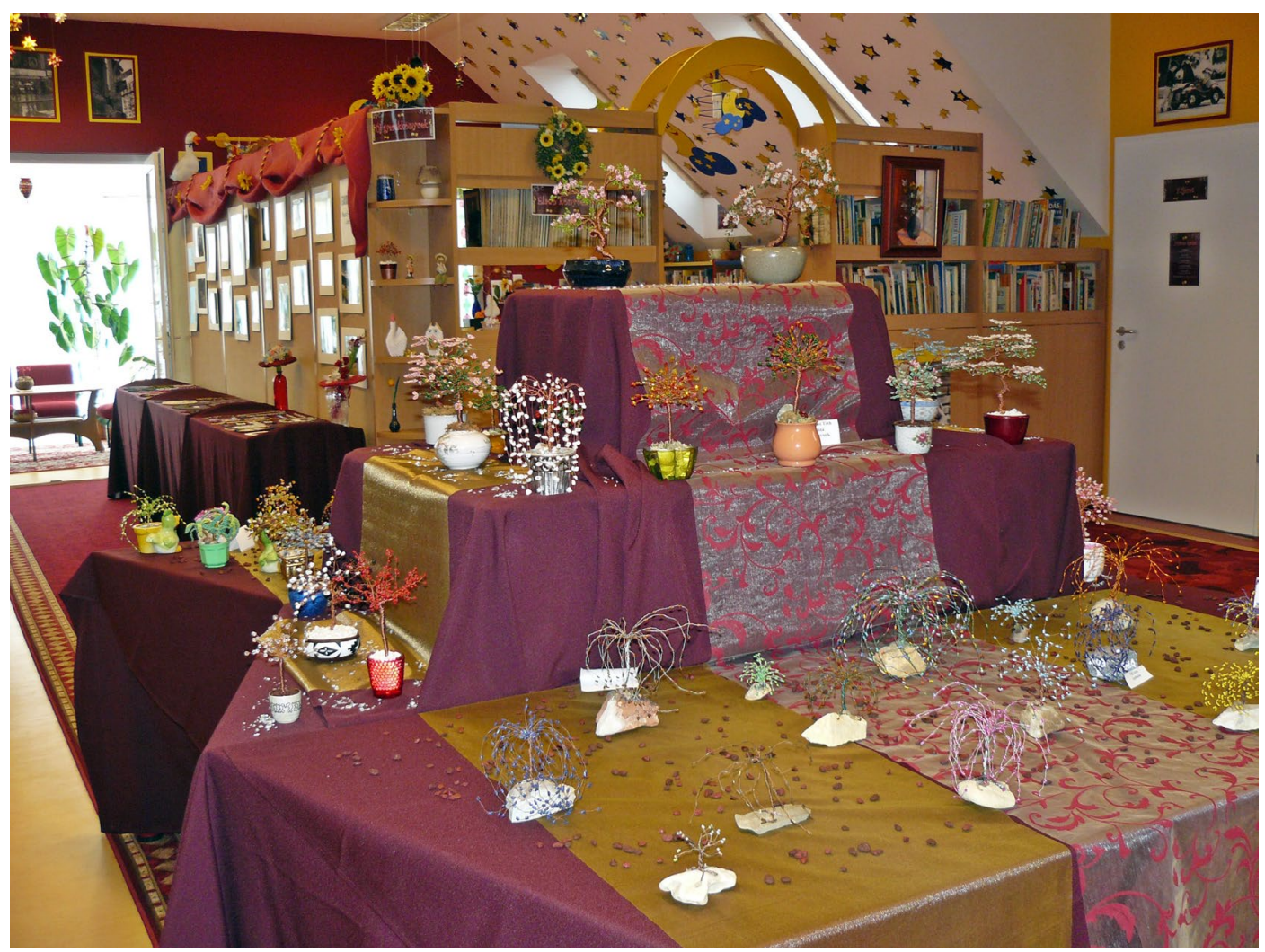


segíteni. A kreatív emberek alapvetően keresik és megtalálják egymás társaságát, de hogy mindezt ne bízzuk a véletlenre, a Zákányszéki Kis Újságban elindult KreA(k)tív címmel egy sorozat, melyben bemutatkozási lehetőséget kínáltunk az amatőr alkotóknak. Arra kértük őket, mutatkozzanak be és mutassák meg szélesebb körben, hogy milyen technikákat alkalmaznak. Bár kicsi faluról van szó, számomra is meglepetés volt, hogy milyen sok háziasszony, családanya, dolgozó nő készít szabadidejében különböző dísztárgyakat, használati eszközöket. Folytatásként a helyi újságban bemutatkozott alkotók munkáit (drótékszerek, papírhajtogatások, gyöngyből készült alkotások) a könyvtárban kiállítás keretében is megtekinthette a közönség. A megnyitóra ellátogattak a rokonok, barátok, szomszédok... közülük néhányan akkor jutottak el elöször a könyvtárba. ${ }^{6}$

Az asszonyok örömmel hozzák el kézimunkáikat, alkotásaikat, hogy azokat másoknak is megmutathassuk. A könyvtárosi hobbi is volt már kiállítási téma a könyvtárban. A gyöngyfa készítése kézműves foglalkozások visszatérő technikája lett, és én örömmel adom át gyerekeknek és felnőtteknek autodidakta módon szerzett ismereteimet. ${ }^{7}$

2011-ben a Csongrád Megyei Könyvtáros Napot Zákányszéken rendeztük meg, ekkor minden kolléga egy-egy gyöngyfát kapott ajándékba emlékül. ${ }^{8}$ A könyvtár meghívott vendégei sem szoktak üres kézzel távozni, így sokaknak van már kreatív darabkája Zákányszékről. A kreativitás ilyen módon találja meg a maga közönségét és közösségét, mely folyamatosan bővül azáltal, hogy a könyvtár bemutatkozási lehetőséget nyújt az alkotóknak.

\section{A közösségépítés teriiletei}

A közösségépítés terén a könyvtár leghangsúlyosabb tevékenysége a rendezvényszervezés. Ennek apropóján az óvodás korúaktól a nyugdíjasokig valamennyi korosztályt meg lehet - és meg kell - szólítani. A könyvtárosok a legkülönbözőbb rendezvényekkel „csalogathatják" a közönséget a könyvtár falai közé. A különböző rendezvények meghatározó szerepet játszanak a helyi közösség életében. Minél szélesebb és színesebb a paletta, annál nagyobb az esély arra, hogy minden korosztály megtalálja a számára ideális programokat. Ha jól érzi magát, szívesen tér vissza és válik a közösség tagjává. Olykor már nehéz megállapítani, hogy a könyvtári közönség szerveződik közösséggé, vagy egy adott közösség azonos érdeklődési körü tagjaiból lesz a könyvtári rendezvények közönsége...?

6 PARAGINÉ Tóth Edina: Zákányszéken így Könyves Vasárnapoztunk. = Zákányszéki Kis Újság, 25. 7. 2015. október 4. Forrás: http://zakanyszek.hu/files/2015/kisujsag/2015_oktober.pdf [2018. november 12.]

7 HORVÁTH Attila: Ékszerfák Zákányszéken. = Délmagyarország, 2012. augusztus 8. 6. p. Forrás: http://www.delmagyar.hu/ szeged_hirek/ekszerfak_zakanyszeken/2292339/ [2018. november 13.]

8 Könyvtárosnap az olvasásért Zákányszéken. = Délmagyarország, 2011. június 28. 6. p.

Forrás: http://www.delmagyar.hu/szeged_hirek/konyvtarosnap_az_olvasasert_zakanyszeken/2227644/ [2018. november 13.] 


\section{1 „Hagyományos” könyvtári rendezvények}

Vannak a klasszikus könyvtári rendezvények, mint pl. író - olvasó találkozók, közönségtalálkozók, előadások, zenés rendezvények, kiállítások, könyvtárhasználati foglalkozások, rendhagyó órák, vetélkedők, olvasásnépszerüsítő játékok... és vannak az „extrémebb”, kevésbé szokványos programok. Zákányszéken mindegyikre van példa, a hagyományos rendezvények közül most két hangsúlyos területet emelnék ki: az általános iskolásoknak tartott rendhagyó könyvtári foglalkozásokat, valamint a felnőtteknek szóló közönségtalálkozókat.

Az iskolai osztályok csoportos látogatása jó lehetőség a könyvtáros számára, hogy pedagógus, játékos, mesélő énjét belevigye egy-egy foglalkozásba. Szívesen bújok különböző szereplők bőrébe, így a gyerekek is könnyebben feloldódnak és partnerek lesznek a játékban. Mesemondás után együtt játsszuk el a mesét jelmezekben, díszletekkel. Kedvelt téma

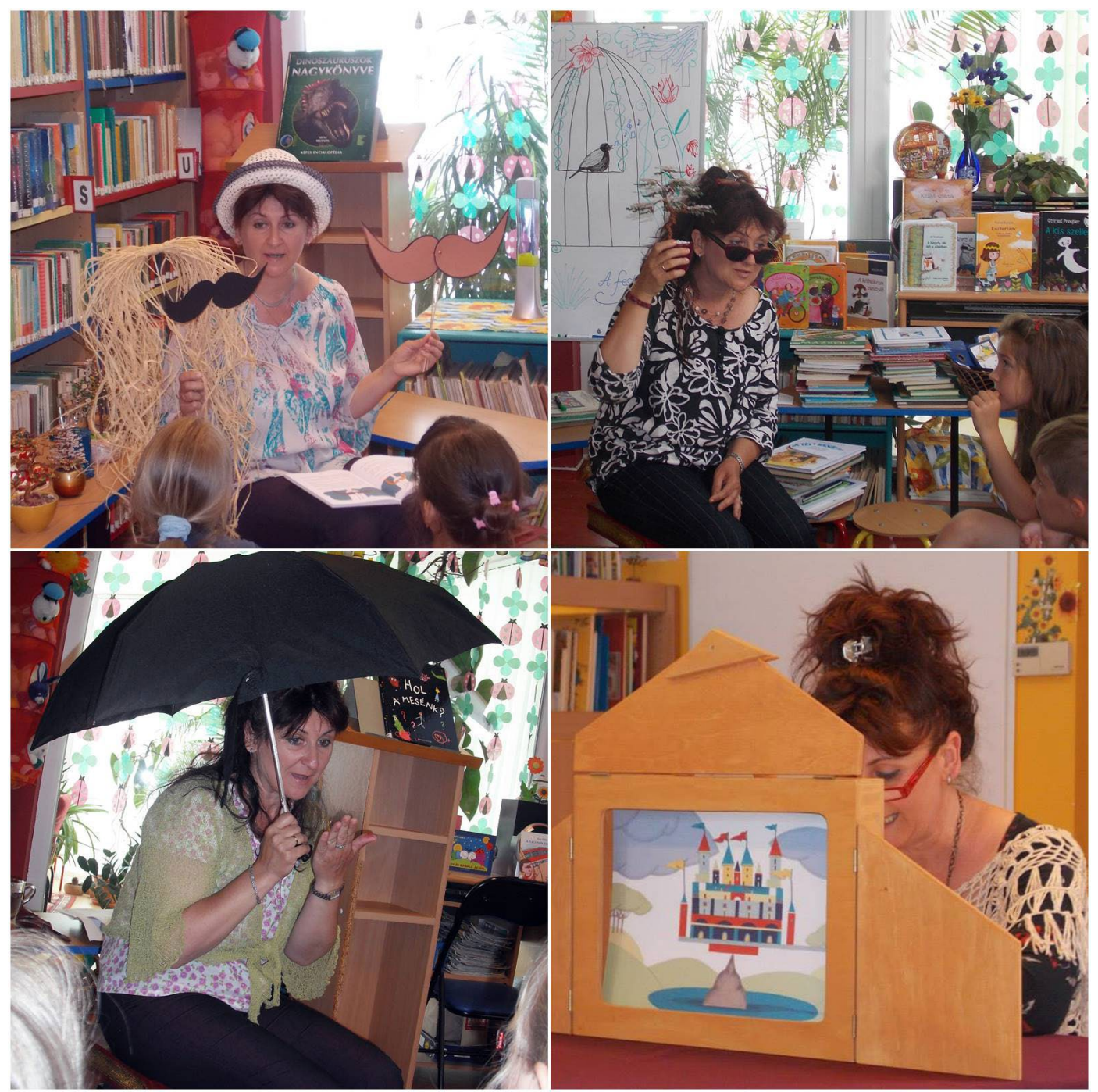


az időutazás Mátyás király udvarába, szeretik a papírszínházat, a fordított napot, amikor ők lehetnek a könyvtárosok, a Márton napi libatáncoltatást... a téma végtelen. Nagyon jó a játékosságban, hogy gyorsan terjed, és semmi mellékhatása nincs, csakis a jókedv és a nevetés. A könyvtári órák a játékos ismeretszerzés mellett ideális közösségépítő alkalmak is egyben.

Nagy élmény a gyerekek számára, amikor „igazi hús-vér” írókkal, költőkkel találkozhatnak a könyvtárban. Ezzel sikerül megcáfolni azt a meglepő kijelentést is, amit egyszer tőlük hallottam. Arra a kérdésre, hogy mi különbség az írók és a költők között, azt a választ adták, hogy a költők olyan írók, akik már nem élnek... Ezért is nagyon fontos a találkozás a XXI. században élő és alkotó írókkal, költőkkel. Mindez közelebb hozza az irodalmat a gyerekekhez, és betekintést nyerhetnek az alkotás folyamatába. A Könyvfaló olvasási játék 2017-es eredményhirdetésén Szabó T. Anna költőnő személyesen adta át a könyvjutalmakat a kis zákányszéki olvasóknak, ami felejthetetlen élmény volt. ${ }^{9}$

Kistelepülésen abban a szerencsés helyzetben vagyok, hogy személyesen ismerem a gyerekeket, az osztályok összetételét, ezért a könyvtári foglalkozásokon differenciált módszereket tudok alkalmazni az egyes osztályoknál. Az eredeti óravázlatokat mindig kicsit módosítom, mintegy „rászabom” az adott osztályra. Csendesebb, nyugodtabb társaságnak inkább mesélek vagy csapatokban dolgoznak, a mozgékonyabb osztályoknak nagyobb mozgásteret engedek, többet játszunk, ők inkább azt igénylik. ${ }^{10}$

A felnőtteknek szervezett író-olvasó találkozók és a különböző tematikájú előadások nagyon népszerűek Zákányszéken, kivétel nélkül teltház előtt zajlanak. Falun különös varázsa van ezeknek a programoknak, mára már a helyi közösség építésének hangsúlyos területeivé váltak. Az ok egyszerü. A személyes találkozásra írókkal, költőkkel, a médiából ismert személyiségekkel kevesebb lehetősége van a vidéki embereknek, mint a városi közönségnek. A könyvtárban „élőben” hallgatni a verseket a költő előadásában, dúdolni a dalokat a Kossuth-díjas zenésszel, kertészeti tanácsokat kérni az országosan ismert kertészmérnöktől, kamasz sorsokat megismerni a Csellengők szerkesztőjétől, közelről látni a televízió képernyőjéről ismert népszerű műsorvezetőket... ezek mind-mind olyan meghatározó élmények, amelyeket sokáig nem felejtenek el a közönség soraiban ülők (olykor állók). Ezért a cél az, hogy minél több programot „helybe hozzunk”. Kistelepülési könyvtárosként minden lehetőséget, pályázati forrást igyekszem megragadni arra, hogy a népszerü vendégeket saját közegünkben köszönthessük. Ebben a szegedi Somogyi-könyvtár nagy segítséget jelent megyei szintü pályázataival, az előadók szervezésével és szállításával. Csak néhány név azok közül, akik az elmúlt években a könyvtár vendégei voltak: Schäffer Erzsébet ${ }^{11}$, Endrei Judit ${ }^{12}$, Süveges

9 PARAGINÉ Tóth Edina: Könyvfaló: avagy egy sikeres olvasási játék útja. = Zákányszéki Kis Újság, 27. 3. 2017. április, 4. p. Forrás: http://zakanyszek.hu/files/2017/kisujsag/2017apr.pdf[2018. november 14.]

10 PARAGINÉ TÓTH Edina: Differenciált könyvtári módszerek Zákányszéken. = Könyvtári Levelező/Lap, 19. 7. (július) 2007. 27-31. p. Forrás: http://epa.oszk.hu/00300/00365/00068/pdf/KLL_EPA00365_2007-07_027-031.pdf[2018. november 14.]

11 Találkozás Schäffer Erzsébettel és Szántó Lukáccsal. = Délmagyarország, 2012. február 1. 6. p. Forrás: http://www.delmagyar.hu/szeged_hirek/talalkozas_schffer_erzsebettel_es_szanto_lukaccsal/2262207[2018. november 12.]

12 Endrei Judit járt a könyvtárban. = Délmagyarország, 2013. március 13. 6. p. Forrás: http://www.delmagyar.hu/szeged_hirek/endrei_judit_jart_a_konyvtarban/2324019/[2018. november 12.] 
Gergö, dr. Bálint György, Huzella Péter, Lackfi János, Szabó T. Anna, Incze Zsuzsa. Ezen kívül vannak egyéb, kevésbé klasszikus közösségépítő rendezvényei is a könyvtárnak, erről a következő fejezetben, az egyesületi programoknál számolok be részletesebben.

\subsection{A civil szféra}

A civil szervezetekkel való jó együttműködés mindig hangsúlyos volt számomra. Kezdetektől fogva igyekeztem minőségi kapcsolatot kiépíteni és fenntartani a helyi civilekkel, kölcsönösen segítve egymás munkáját. A „civilség” még hangsúlyosabbá vált a munkámban, amikor 2008-ban magam is alapító tagja lettem a ZakaHom-e Egyesületnek. Ez a csapatmunka tökéletesen kompenzálja az egyszemélyes könyvtárosságból fakadó hátrányokat, korlátokat. A folytatásban olyan nagyobb volumenü rendezvényekről szeretnék összefoglalást nyújtani, amelyeket egyedül képtelenség lett volna megvalósítani. A lehetőség azonban ott rejtőzött a civil szférában, a tudatos csapatmunka erejében.

\subsubsection{A ZakaHom-e Egyesület}

Ami egyedül nem megy, az megy egy nagyszerű csapat tagjaként. A ZakaHom-e Egyesületben egy olyan csapatba tartozhatok, ahol együtt ápoljuk a helyi hagyományokat, de jövőbe mutató újító kezdeményezéseket is sikerült elindítanunk. A hivatalossá válásunkat kissé megelőzve, 2007 novemberében meghirdettük az első múltidéző vetítést, decemberben pedig jelentkeztünk egyesületünk nyomtatott hírlevelével, a Zákányszéki Életképekkel. ${ }^{13}$ Azóta sok egyesületi rendezvény valósult meg a könyvtáron belül, de a munka gyakran túllép a könyvtár falain. Mivel mindannyiunknak megvan a maga főfoglalkozása, eleinte nehéz volt összeegyeztetni a sok szabadidőt igénylő egyesületi tevékenységgel. Idővel az egyesületi törekvések szépen belesimultak elsődleges feladatkörünkbe, mintegy kiegészítve, továbbgondolva azt. Nem is kell, nem is lehet különválasztani, hiszen a cél közös. Zákányszékért, az itt élőkért tenni, dolgozni minél több formában, minél több területen.

\subsubsection{Múltidéző vetítések}

Az egyesület szervezésében 11 évvel ezelőtt indultak el a múltidéző vetítések, melyek azóta a leghangsúlyosabb hagyományteremtő rendezvényeink körébe tartoznak. Az eredetileg csak néhány alkalomra tervezett vetítéseken a mai napig teltház előtt peregnek a filmek. A kiindulást azok a régi S8-as felvételek jelentették, melyek az 1960-as évektől örökítették meg a település ünnepeit és hétköznapjait. A filmeket digitalizáltuk, majd bemutattuk a közönségnek. Céljaink összetettek voltak: a digitalizálással az archív anyagok megőrzését szerettük volna biztosítani, a nyilvános vetítéssekkel pedig a gyüjtemény közkincsé tételére és a közösségépítésre törekedtünk. ${ }^{14}$ Látva a nem múló érdeklődést múltunk vizuális gyöngyszemei iránt, több szálon indítottuk el a folytatáshoz az anyaggyüjtést. Felvettük a

13 Zákányszéki Életképek. A ZakaHom-e Egyesület folyóirata. Különszám. 2017. december Forrás: http://zakanyszek.hu/files/2017/kisujsag/2017eletkepek.pdf [2018. november 12.]

14 TANÁCS István: Zákányszéki múltidézők. = Szabad Föld Kalendárium, 2018. 64-65. p. 
kapcsolatot a Magyar Televízió Archívumával és a Szegedi Körzeti Stúdióval, valamint arra kértük a lakosságot, hogy a családi fotóalbumokat hozzák el a könyvtárba, hogy a régi fotókat feldolgozzuk és rendszerezzük. Reméltük, hogy ezek a fotók nemcsak a családok életéröl, hanem a település múltjáról és hagyományairól is árulkodnak majd. Tematikusan és időrendben rendszereztünk több száz képet, melyek újabb vetítési anyagként szolgáltak. Igyekeztünk a képeken látható személyeket nevesíteni, de már a fotók tulajdonosai sem tudtak mindenkire visszaemlékezni. Ezért vetítéskor a közönséget kértük a szereplők azonosítására, ez számunkra nagy segítség volt, a jelenlévőknek pedig egy érdekes játék. ${ }^{15} \mathrm{Az}$ interaktív „képfelismerős” vetítésnek volt egy mindannyiunk számára megható pillanata. A helyi amatőr színjátszás fotóinak bemutatását egy különleges produkció zárta. A Mézeskalács c. színdarab két egykori szereplőjét arra kértük, hogy 50 év elteltével énekeljék el újra egykori duettjüket. Miközben a vásznon láthattuk őket fiatal szereplőkként, a közönség előtt állva kissé remegő hangon, immár fehér hajjal újra dalra fakadtak...A vetítések során szembesültünk azzal a felismeréssel, hogy nemcsak gyüjtenünk és publikálnunk kell az anyagokat, hanem felelősek vagyunk a jelen eseményeinek megörökítéséért is. Minél gyorsabban igyekeztünk megteremteni a megfelelő technikai hátteret, kamerát, mikrofont vásároltunk és 2010ben elkészítettük az első riportunkat. Azóta folyamatosan jelen vagyunk a helyi rendezvényeken a báli szezontól egészen a falukarácsonyig. Külső helyszíneken is forgatunk, sőt útifilmet is készítettünk már erdélyi testvértelepülésünkön, Borszéken. ${ }^{16}$ Ezek a felvételek újabb vetítési témákat jelentenek, és mi egy évtized után is teltház előtt vetítünk.

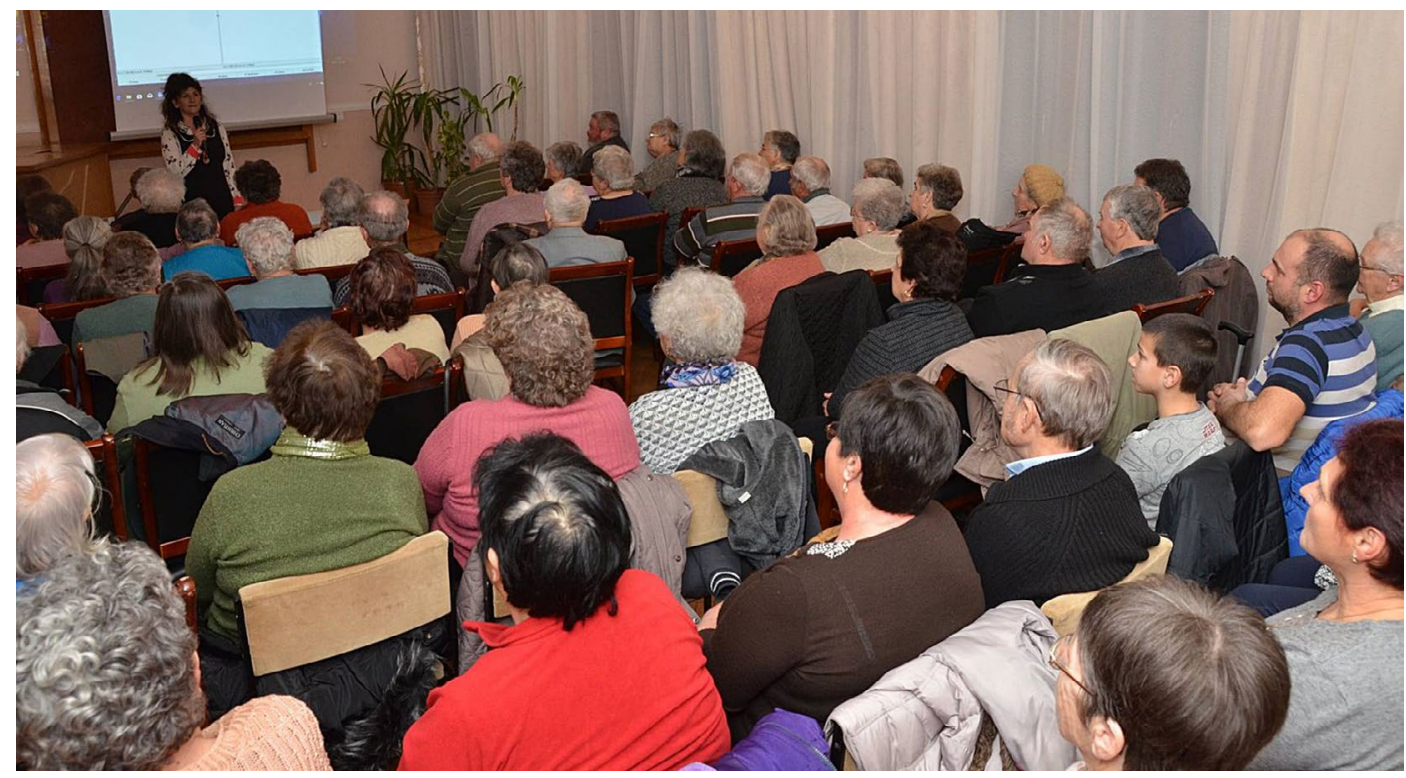

4. kép: Teltházas vetités 2018-ban

15 PARAGINÉ Tóth Edina: Együtt. Keresd - mutasd - ismerd fel: Múltidézés Zákányszéken. = Könyv, Könyvtár, Könyvtáros, 26. 4. 2017. 31-37. p. Forrás: http://ki2.oszk.hu/3k/2017/05/egyutt-keresd-\%E2\%80\%93-mutasd-\%E2\%80\%93-ismerd-fel/ [2018. november 12.]

16 ARANY T. János: Nem kell áram a boldogsághoz. Testvértelepülésükön, Borszéken forgattak útifilmet a zákányszékiek. = Délmagyarország, 2016. április 13. 6. p. Forrás: http://www.delmagyar.hu/szeged_hirek/nem_kell_aram_a_ boldogsaghoz/2470590/ [2018. november 10.] 


\subsubsection{Jótékonysági kezdeményezések}

Ahol tudunk, igyekszünk segíteni. Ez a szándék szintén a helyi közösség fejlődését szolgálja, még akkor is, ha ebben az esetben nem ez az elsődleges cél. Néhány példa erre: a templomban vetítéssel egybekötött előadást hirdettünk egy bajba jutott család megsegítésére, részt vállaltunk jótékonysági gálaest szervezésében, egyesületi felajánlással hozzájárultunk egy mütét sikeréhez ${ }^{17}$, gyüjtést hirdettünk az önkormányzattal együttmüködve a borszéki gyermekotthon javára. Jó érzés látni az emberek összefogását, segítő szándékát, amint a hívó szóra megmozdulnak és tenni akarnak a bajba jutottakért.

\subsubsection{Ifjú tehetségek}

A hagyományok ápolása, megőrzése mellett legalább annyira fontos a jelen értékeinek és értékes embereinek a megismerése és megismertetése. Ehhez legtöbbször elég csak nyitott szemmel járni-kelni, és észrevenni a környezetünkben élő fiatal tehetségek ambícióját. Öket további elképzeléseik megvalósításához segítheti hozzá egy-egysikeres rendezvény. Lehet, hogy csak egy kiállítás, vagy egy önálló est megszervezésére van szükség ahhoz, hogy el tudjanak indulni az útjukon... Ilyen egyesületi kezdeményezés volt 2013 tavaszán Hegedűs Bettina első önálló zongoraestje. Komolyzenei koncert egy kistelepülés művelődési házában? Igen, ha a cél motiválja a közönséget. Ezen az estén a zákányszéki tanyavilágban élő tehetséges zongorista lány teltház elött játszott és varázsolta el a közönséget. A zenei blokkok között a színpadon beszélgettem vele és tanárnőjével. A koncertre érkezők különböző öszszegű támogatójegyek vásárlásával járultak hozzá, hogy Bettina a tervezett zeneakadémiai tanulmányait elkezdhesse. A koncert után egy összegben nyújtottuk át a befolyt összeget, és ősszel érkezett a hír, hogy felvételt nyert a Zeneművészeti Egyetemre. Felemelő érzés volt, hogy ehhez kicsit mi is hozzájárulhattunk. ${ }^{18} \mathrm{~A}$ szintén zákányszéki születésủ Vass Károly közösségi oldalán figyeltünk fel gyönyörü természetfotóira, és hamarosan kiállítási lehetöséget kínáltunk számára a könyvtárban. A megnyitót összekötöttük Süveges Gergő közönségtalálkozójával, ami külön megtiszteltetés volt az ifú fotós számára. „1 csepp Alföld” című kiállítása nagy sikert aratott, azóta bátran mutatja meg fotóit másoknak is. Nemrégiben különdíjat vehetett át a mórahalmi Rotary Klub által rendezett „Papírra vetve” pályázaton.

\subsubsection{Kerékpártúrák}

Egyesületünk 2013-ban indította el a ZakaHom-e kerékpártúrákat. ${ }^{19}$ Éves szinten több száz km-t kerékpározunk a sportbarát csapattal. Ezek a túrák újabb lehetőséget jelentenek a közösségépítés területén. Valljuk, hogy „ép testben ép lélek”, és az első túrák óta azt is tudjuk, hogy a kerékpározás nem csak egészséges, hanem közösségépítő erejű sport is. Jó kapcsolat alakult ki

1750 ezer forintot ér a rekord gyöngyfa. = Délmagyarország, 2015. február 18. 6. p.

Forrás: http://www.delmagyar.hu/szeged_hirek/50_ezer_forintot_er_a_rekord_gyongyfa/2418183/ [2018. november 13.]

18 HEGEDÜS Bettina zongoraestje. = Délmagyarország, 2013. március 13. 6. p.

Forrás: http://www.delmagyar.hu/szeged_hirek/hegedus_bettina_zongoraestje/2324017 [2018. november 12.]

19 Biciklis Zákányszék. = Délmagyarország, 2013. július 24. 6. p.

Forrás: http://www.delmagyar.hu/szeged_hirek/biciklis_zakanyszek/2342740/ [2018. november 12.] 
más biciklis szervezetekkel, közös programokban is tudunk már gondolkodni. Azóta már több ezres nagyságrendben mérhető a lelkes csapattal megtett kilométerek száma. ${ }^{20} \mathrm{~A}$ kerékpározás szeretete és közösségkovácsoló ereje mellett könyvtárosként azt is nagyon jó látni, hogy a kerékpártúrák résztvevői hogyan lesznek nyitottak a könyvtári rendezvényekre és válnak rendszeres látogatókká. A kerékpározásnak köszönhetően készítettek már velünk olyan riportot, amely anyag vetítése elsősorban a kerékpárbarát közönséget vonzotta be a könyvtárba.

\subsubsection{Még néhány újdonság...}

A végére maradt még néhány olyan kezdeményezés, amely közvetve vagy közvetlenül a könyvtárba mozgósította az embereket. A régi idők amatőr színjátszása adta az ötletet, hogy helybe hozzuk a színházat. Elhívtuk a szomszédos településről a Mórahalmi Színtársulatot, hogy vendégszerepeljenek nálunk. A jegyárusítás a könyvtárban zajlott, így a teltházas előadás előtt sokan megfordultak a könyvtárban. Az előadás utáni állófogadás helyszíne szintén a könyvtár volt, néhány amatőr színész meg is ragadta az alkalmat és beiratkozott, kölcsönzött.

2016-ban megszerveztük a „Máriás-lányok” találkozóját. Egy közel 60 éves csoportkép volt a kiindulópontja a komplex rendezvénynek. Felkutattuk a fényképen látható fehérlányokat (hajadon lányok, akik az egyházi ünnepeken fehér ruhába öltöztek) és egy különleges estére hívtuk el őket: szentmisére a templomba, filmes-fotós nosztalgiázásra a művelődési házba, aratókoszorúkat bemutató kiállításra a könyvtárba. ${ }^{21} 2017$ decemberében pedig Vincze Lilla énekesnő adventi koncertjére hívtuk a közönséget a templomba. Ilyen korábban még nem volt Zákányszéken. Ezzel a koncerttel szerettünk volna mi magunk is egy kicsit megállni, erőt meríteni a folytatáshoz, megköszönni az emberek szeretetét, az egy évtizedes bizalmat, a kitartó érdeklődést... azt, hogy ebben a közösségben, melyet Zákányszék lakossága alkot, otthon vagyunk és számíthatunk egymásra.

\subsection{Közönség, kontra közösség}

Az eddig bemutatott példák jól tükrözik, hogy olyan rendezvényeknek is bázisa lehet a könyvtár, amelyek nem konkrétan a könyvtárban valósulnak meg, de a könyvtár(os)nak mégiscsak „köze van” hozzá. Az egyesületi lét nagyot nyitott ebbe az irányba, hiszen ha közvetlenül vagy közvetett módon a közönségszervezés folyamatába a könyvtár, mint hely bevonódik, akkor a véletlenszerü könyvtárba járást lehet egy kicsit irányítani. Sokan lettek a rendezvények spontán résztvevői közül rendszeresen könyvtárba járók. Ehhez elég volt megszólítani őket, kedvet csinálni egy számukra érdekes programmal, és az életükbe akkor is belopózott a könyvtár, ha korábban az olvasás nem motiválta erre őket. Így épülhet közönségből közösség, és egy közösség tagjaiból a könyvtár közönsége.

20 BAKOS András: 1600 kilométert teker évente a zákányszéki kemény mag. = Délmagyarország, 2016. március 2. 6. p. Forrás: http://www.delmagyar.hu/szeged_hirek/1600_kilometert_teker_evente_a_zakanyszeki_kemeny_mag/2465479/ [2018. november 12.]

21 TANÁCS István: Fehér lányok felöltöztek. = Szabad Föld, 73. 51-52. 2018. 12-13. p.

Forrás: https://www.szabadfold.hu/aktualis/riport_feher_lanyok_feloltoztek [2018. november 13.] 


\section{Marketing}

A helyi adottságok maximális kihasználása mellett a könyvtárosnak számos eszköz van a kezében arra, hogy intézményével jelen legyen a köztudatban. Ha jól kommunikál a külvilág felé, ha folyamatosan tájékoztat honlapon, helyi újságokban, közösségi médiában a könyvtárban történtekről, ha jó kapcsolatot ápol az intézményekkel és a civil szervezetekkel, akkor valamennyi réteghez el tud jutni. A könyvtár beékelődik a köztudatba és nem érhetik olyan vádak, hogy a könyvtárban nem történik semmi...csak azért, mert nem tudnak róla.

\subsection{Kiadványaink, honlapok}

Fontos, hogy ami a környezetünkben történik, arról minél több csatornán keresztül hírt adjunk, minél több emberhez eljuttassuk az aktuális híreket, információkat. A könyvtár szerepvállalása a helyi újságok kiadásában több szálon is fut. Két helyi lap - Zákányszéki Kis Újság és a Zákányszéki Életképek - szerkesztőbizottságában tevékenykedek. A Kis Újság szerkesztőségi munkájához kb. 15 évvel ezelőtt csatlakoztam, saját kezdeményezésből. Azt kértem tőlük, hogy nyomdába kerülés előtt a stilisztikai és betühibákat korrigálhassam. Cserébe egy kis helyet kértem a lapban, ahol elindítottam a könyvtári rovatot hírekkel, játékos feladványokkal, idézetekkel. 2008-ban a frissen alakult egyesületünk lett az újság felelős kiadója. Ekkor lettem hivatalosan is szerkesztőbizottsági tag. A szerkesztőségi megbeszélések helye a könyvtár,

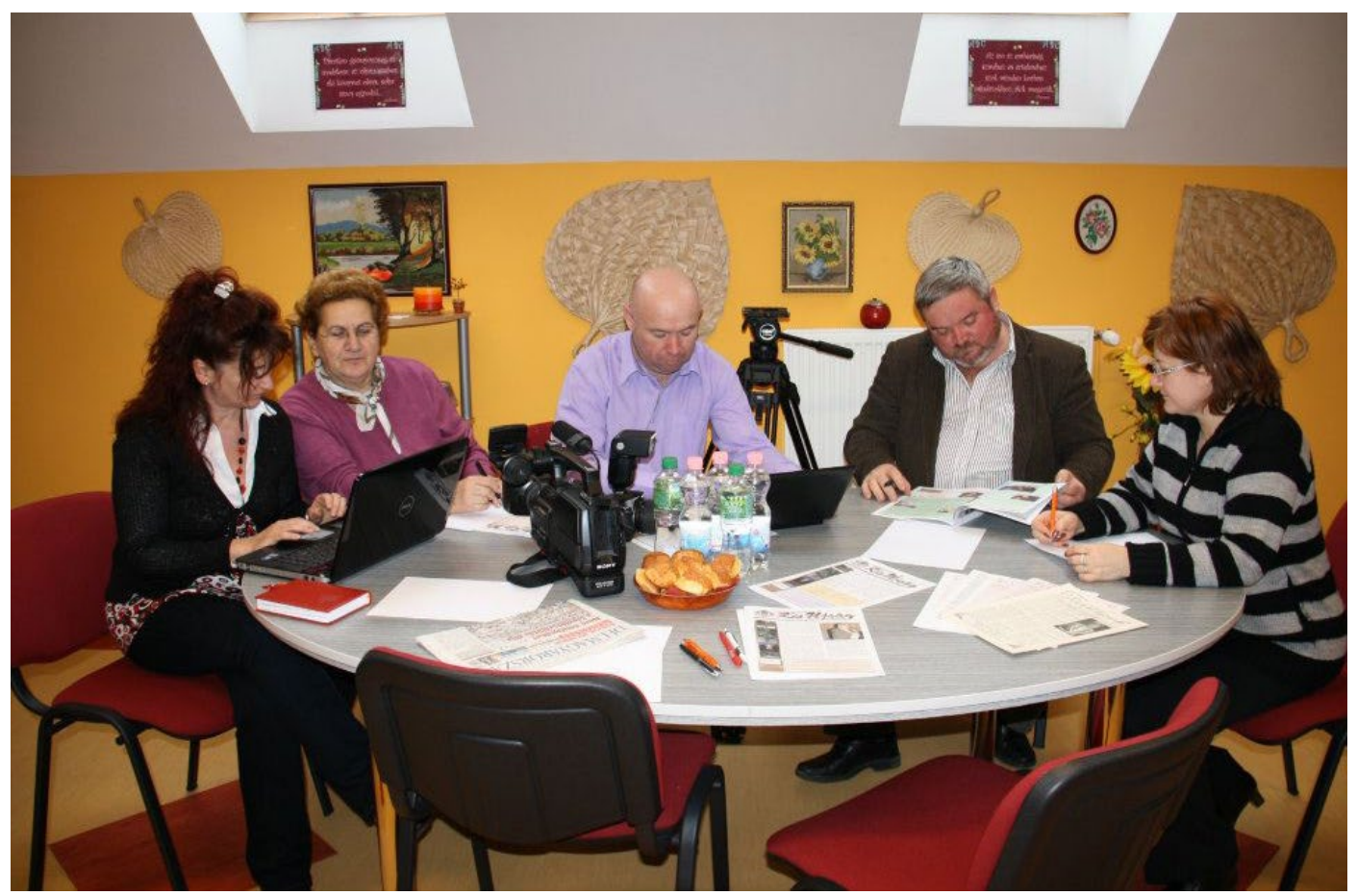

5. kép: Szerkesztöbizottsági munka a könyvtárban 
rendszeresen itt találkozunk és megbeszéljük a feladatokat. A szerkesztési és nyomdatechnikai munkafolyamatok sokat változtak az elmúlt években, a beérkezett anyagokat „felhőben” (Dropbox) tároljuk, itt is javítjuk. Gyorsabban és hatékonyabban tudunk így dolgozni. ${ }^{22}$

A nyomtatott újságok 1100 példányban készülnek és minden zákányszéki háztartásba ingyenesen jutnak el a helyi posta terjesztésével. Fontos, hogy elektronikusan szélesebb körben, más felhasználóknak is hozzáférhetővé tegyük a kiadványokat. A cikkek Zákányszék honlapján online olvashatóak a Kiadványaink menüben. Médiacsoportunk szerkeszti és friss hírekkel tölti fel a www.zakanyszek.hu oldalt, a www.zakihirek.hu oldalt, valamint tájékoztatást nyújtunk egyesületünk honlapján, a www.zakahome.hu oldalon. ${ }^{23}$

\subsection{Közösségi média}

A közösségi média segítségével sokakhoz el tudjuk juttatni a települési és a könyvtári információkat, híreket. Nemrég indult el a könyvtár önálló honlapja a konyvtar.zakanyszek.hu oldalon, ahol az olvasók a hasznos információkon kívül online is kereshetnek a könyvtár adatbázisában, hosszabbítást kezdeményezhetnek a kölcsönzésben lévő könyvekre. A közösségi oldalon is igyekszünk naprakészek lenni, minden fontos hírről, rendezvényről beszámolni, fotókat feltölteni, napi szinten tartani a kapcsolatot az olvasókkal. A „zakihirek” Youtube csatornánkon kb. 400 saját készítésű anyag látható 230 ezres megtekintéssel.

\section{Összegzés}

A tartalom változik, de a cél állandó marad: szolgáltatni, értéket közvetíteni, élményt nyújtani a közösség tagjainak, akiket egy láthatatlan szál köt össze mindennél erősebben. Ebben az összetartozásban rejlik múltunk, jelenünk és a jövőnk! Nem lehetőségünk, hanem kötelességünk tovább vinni elődeink örökségét, megismerni és feltárni a jelen értékeit... nincs mire várni, a 24. órában járunk! Legyen a könyvtár mindenkori bázisa a helyi közösségnek, a könyvtáros pedig mozgatója a közösség fejlödésének.

22 BARÁTNÉ HAJDU Ágnes: Zákányszék és Paraginé Tóth Edina a World Press Freedom Day 2018 egyik példája az IFLA blogjában. Forrás: https://mke.info.hu/blog/2018/06/zakanyszek-es-paragine-toth-edina-a-world-press-freedom-day-2018-egyik-peldajaaz-ifla-blogjaban/ [2018. november 14.]

232500 perc Zákányszékről. = Délmagyarország, 2012. január 11. 6. p. Forrás: http://www.delmagyar.hu/szeged_hirek/2500_ perc_zakanyszekrol/2258411[2018. november 12.] 


\section{Irodalom}

50 ezer forintot ér a rekord gyöngyfa. = Délmagyarország, 2015. február 18. 6. p. Forrás:http://www. delmagyar.hu/szeged_hirek/50_ezer_forintot_er_a_rekord_gyongyfa/2418183 [2018. október 31.]

2500 perc Zákányszékről. = Délmagyarország, 2012. január 11. 6. p. Forrás: http://www.delmagyar.hu/ szeged_hirek/2500_perc_zakanyszekrol/2258411 [2018. október 31.]

ARANY T. János: Nem kell áram a boldogsághoz. Testvértelepülésükön, Borszéken forgattak útifilmet a zákányszékiek. = Délmagyarország, 2016. április 13. 6. p. Forrás: http://www.delmagyar.hu/szeged_ hirek/nem_kell_aram_a_boldogsaghoz/2470590/ [2018. október 31.]

BAKOS András: 1600 kilométert teker évente a zákányszéki kemény mag. = Délmagyarország, 2016. március 2. 6. p. Forrás: http://www.delmagyar.hu/szeged_hirek/1600_kilometert_teker_evente_a_zakanyszeki_kemeny_mag/2465479/[2018. október 31.]

BAKOS András: Alaszkából 14 nap alatt Zákányszékre ér a kért könyv. = Délmagyarország, 2013. február 4. 8. p. Forrás: http://www.delmagyar.hu/szeged_hirek/alaszkabol_14_nap_alatt_zakanyszekre_ er_a_kert_konyv/2318318/ [2018. október 31.]

BARÁTNÉ HAJDU Ágnes: Zákányszék és Paraginé Tóth Edina a World Press Freedom Day 2018 egyik példája az IFLA blogjában. Forrás: https://mke.info.hu/blog/2018/06/zakanyszek-es-paraginetoth-edina-a-world-press-freedom-day-2018-egyik-peldaja-az-ifla-blogjaban/ [2018. október 31.]

Biciklis Zákányszék. = Délmagyarország, 2013. július 24. 6. p. Forrás: http://www.delmagyar.hu/ szeged_hirek/biciklis_zakanyszek/2342740/[2018. október 31.]

Endrei Judit járt a könyvtárban. = Délmagyarország, 2013. március 13. 6. p. Forrás: http://www. delmagyar.hu/szeged_hirek/endrei_judit_jart_a_konyvtarban/2324019/ [2018. október 31.]

Hegedüs Bettina zongoraestje. $=$ Délmagyarország, 2013. március 13. 6. p. Forrás: http://www. delmagyar.hu/szeged_hirek/hegedus_bettina_zongoraestje/2324017 [2018. október 31.]

HORVÁTH Attila: Ékszerfák Zákányszéken. = Délmagyarország, 2012. augusztus 8. 6. p. Forrás: http://www.delmagyar.hu/szeged_hirek/ekszerfak_zakanyszeken/2292339/ [2018. október 31.]

Könyvtárosnap az olvasásért Zákányszéken. = Délmagyarország, 2011. június 28. 6. p. Forrás: http:// www.delmagyar.hu/szeged_hirek/konyvtarosnap_az_olvasasert_zakanyszeken/2227644/ [2018. október 31.]

MIKULÁS Gábor: A könyvtári ellátás korszerű formái az EU-ban: Antwerpen, Zákányszék, Madrid... Forrás: http://www.kithirlevel.hu/index.php?kh=a_konyvtari_ellatas_korszeru_formai_az_eu-ban_ antwerpen_zakanyszek_madrid [2018. október 31.]

PARAGINÉ TÓTH Edina: Differenciált könyvtári módszerek Zákányszéken. = Könyvtári Levelezö/Lap, 19. 7. (Július) 2007. 27-31. p. Forrás: http://epa.oszk.hu/00300/00365/00068/pdf/KLL_ EPA00365_2007-07_027-031.pdf [2018. október 31.]

PARAGINÉ TÓTH Edina: Együtt. Keresd - mutasd - ismerd fel! Múltidézés Zákányszéken. = Könyv, Könyvtár, Könyvtáros, 26. 4. 2017. 31-37. p. Forrás: http://ki2.oszk.hu/3k/2017/05/egyutt-keresd\%E2\%80\%93-mutasd-\%E2\%80\%93-ismerd-fel/ [2018. október 31.]

PARAGINÉ TÓTH Edina: Könyvfaló: avagy egy sikeres olvasási játék útja. = Zákányszéki Kis Újság, 27. 3. 2017. április, 4. p. Forrás: http://zakanyszek.hu/files/2017/kisujsag/2017apr.pdf [2018. október 31.]

PARAGINÉ TÓTH Edina: Zákányszéken így Könyves Vasárnapoztunk. = Zákányszéki Kis Újság, 25. 7. 2015. október, 4. p. Forrás: http://zakanyszek.hu/files/2015/kisujsag/2015_oktober.pdf [2018. október 31.]

Találkozás Schäffer Erzsébettel és Szántó Lukáccsal. = Délmagyarország, 2012. február 1. 6. p. Forrás: http://www.delmagyar.hu/szeged_hirek/talalkozas_schffer_erzsebettel_es_szanto_lukacscsal/2262207 [2018. október 31.] 
TANÁCS István: Fehér lányok felöltöztek. = Szabad Föld, 73. 51-52. 2017. 12-13. p. Forrás: https:// www.szabadfold.hu/aktualis/riport_feher_lanyok_feloltoztek [2018. október 31.]

TANÁCS István: Zákányszéki múltidézők. = Szabad Föld Kalendárium, 2018. 64-65. p. [2018. október 31.]

Tündérkönyvtáros Zákányszéken. = Délmagyarország, 2014. július 2. 6. p. Forrás: http://www. delmagyar.hu/szeged_hirek/tunderkonyvtaros_zakanyszeken/2388422/ [2018. október 31.]

Vámpírokért és Babócáért jön az olvasó. = Délmagyarország, 2010. november 24. 6. p. Forrás: http://www. delmagyar.hu/szeged_hirek/vampirokert_es_babocaert_jon_az_olvaso/2190401 [2018. október 31.]

ZakaHom-e Egyesület. Paraginé Tóth Edina több mint 30 éve a köz szolgálatában. Forrás: http://www.zakahome.hu/2016/02/09/paragine-toth-edina-tobb-mint-30-eve-a-koz-szolgalataban/ [2018. október 31.]

Zákányszéki Életképek. A ZakaHom-e Egyesület folyóirata. Különszám, 2017. december Forrás: http://zakanyszek.hu/files/2017/kisujsag/2017eletkepek.pdf [2018. október 31.]

Paraginé Tóth Edina 1986-ban kezdett el dolgozni a zákányszéki művelődési házban, 1988 óta könyvtáros. Alapító tagja a ZakaHom-e Egyesületnek, tagja a helyi újságok szerkesztő bizottságának. Több cikluson keresztül tagja a Csongrád Megyei Könyvtáros Egyesület vezetőségének. A kistelepülési könyvtárak menedzselésének kérdéseiről és a helytörténeti jelentőségéről több előadást tartott különböző konferenciákon. 2011-ben Az Év könyvtára kitüntető címre nyújtott be figyelemreméltó pályázatot. 